\title{
Development of eight novel microsatellite markers for Huoyan geese
}

\author{
Z.Z. Cao, D. Su, Y.Y. Zhao, M. Liu, M. Gao and X.H. Luan \\ College of Animal Science and Veterinary Medicine, \\ Shenyang Agricultural University, Shenyang, Liaoning, China \\ Corresponding author: X.H. Luan \\ E-mail: xhluan@163.com
}

Genet. Mol. Res. 13 (3): 5562-5565 (2014)

Received July 1, 2013

Accepted October 29, 2013

Published July 25, 2014

DOI http://dx.doi.org/10.4238/2014.July.25.10

\begin{abstract}
In this study, we isolated microsatellite DNA from the Huoyan goose genome with magnetic beads. As a result, 150 positive clones were identified, and 148 microsatellites were found. Among the 148 microsatellites, $69.6 \%$ were perfect, $17.6 \%$ were imperfect, and the rest were compound type (12.8\%). Twenty microsatellite primers were used to screen 90 individuals from 3 Huoyan goose populations. Eight loci were polymorphic with a low number of alleles (2 to 4$)$. The observed and expected heterozygosities ranged from 0.3556 to 1 and from 0.2923 to 0.6868 , respectively. All the 8 polymorphic loci were in Hardy-Weinberg equilibrium. These molecular markers will be useful for future studies on population genetic structure and conservation genetics in Huoyan geese.
\end{abstract}

Key words: Huoyan geese; Microsatellite; Molecular marker 


\section{INTRODUCTION}

The Huoyan goose is an excellent local goose variety, which was listed as one of the nationally protected domestic animals by the Chinese government in the year 2000. It has a lot of merits, including higher laying performance, no broodiness, high fertility, and resistance to cold and roughage. Because of the lack of a scientific selection system and cultivation methods, genetic varieties of Huoyan geese were not protected perfectly. The preservation of this waterfowl breed genome is one of the priorities in goose breeding. The loss of the genetic variety will eliminate unique genetic traits, providing fewer chances to improve Huoyan goose breeds in the future. Creating specific molecular markers is essential to achieve this aim. Microsatellites, also known as simple sequence repeats (SSRs), are highly polymorphic and abundant genetic markers ( $\mathrm{Li}$ et al., 2002). They were widely employed in population genetic studies of numerous species, including poultry (Cheng and Crittenden, 1994; Kamara et al., 2007). Here, we developed and characterized 8 novel microsatellite markers for Huoyan geese, which will be useful for future studies on the population genetic structure and conservation genetics in this species.

\section{MATERIAL AND METHODS}

Genomic DNA was extracted from blood samples of 3 Huoyan goose populations in Liaoning Province, Liaoyang (LY), Panjin (PJ), and Changtu (CT), using the Blood Genome DNA Extraction kit (Sangon Biotechnology, Shanghai, China) following manufacturer instructions. Then, the DNA samples were pooled and digested with Sau3AI (MBI Fermentas, Vilnius, Lithuania). Theresulting DNAfragments, whichrangedinsize from 300 to $1000 \mathrm{bp}$, were recovered and ligated to the adaptors (Linker A: 5'-GATCGTCGACGGTACCGAATTCT-3' and Linker B: 5'-GTCAAGAATTCGGTACCGTCGAC-3') (Brown et al., 1995) with T4 DNA ligase (Promega, Madison, WI, USA). The fragments with adaptors were amplified via polymerase chain reaction (PCR) using Linker B as a primer with the following program: pre-denaturation at $94^{\circ} \mathrm{C}$ for $3 \mathrm{~min} ; 20$ cycles of denaturation at $94^{\circ} \mathrm{C}$ for $1 \mathrm{~min}$, annealing at $58^{\circ} \mathrm{C}$ for $1 \mathrm{~min}$, and elongation at $72^{\circ} \mathrm{C}$ for $2 \mathrm{~min}$; and a final extension at $72^{\circ} \mathrm{C}$ for $10 \mathrm{~min}$. The amplified DNA fragments were denatured at $95^{\circ} \mathrm{C}$ for $5 \mathrm{~min}$ and then hybridized to biotinlabeled (CA) ${ }_{15}$ probes (Sangon Biotechnology) in $50 \mu \mathrm{L}$ hybridization solution at $68^{\circ} \mathrm{C}$ for $1 \mathrm{~h}$. The DNA hybridized to the probe was separated and captured by streptavidin magnetic beads (Promega) at room temperature for $20 \mathrm{~min}$, which was followed by nonspecific and specific washing. The beads were first washed twice in low stringency conditions [room temperature in $6 \mathrm{X}$ saline sodium citrate (SSC), $0.1 \%$ sodium dodecyl sulfate (SDS), 10 min each]. Then, the beads were washed 4 times in high stringency conditions (twice in $3 \mathrm{X}$ SSC at $68^{\circ} \mathrm{C}, 0.1 \% \mathrm{SDS}, 15 \mathrm{~min}$ each; twice in $6 \mathrm{X} \mathrm{SSC}$ at room temperature). Finally, the beads were eluted as single-stranded fragments using $0.1 \mathrm{X}$ Tris-ethylenediaminetetraacetic acid at room temperature. The final elution served as a template for PCR amplification using the same program mentioned above. The PCR products were purified, ligated to the pMD 18-T vector (TaKaRa, Dalian, China), and transformed into Escherichia coli DH5 $\alpha$ competent cells. Positive clones were detected by PCR using the Linker B and (CA) $)_{15}$ primers. All PCR reactions were performed under the following conditions: initial denaturation of 3 min at $94^{\circ} \mathrm{C} ; 25$ cycles of $1 \mathrm{~min}$ at $94^{\circ} \mathrm{C}, 30 \mathrm{~s}$ at $55^{\circ} \mathrm{C}$, and $30 \mathrm{~s}$ at $72^{\circ} \mathrm{C}$; and a final 
extension at $72^{\circ} \mathrm{C}$ for $10 \mathrm{~min}$. One hundred fifty positive colonies were randomly selected and sequenced on an ABI 3730 automated sequencer. After removing the vector sequences by comparison to vector sequences deposited in the GenBank database (searched by the basic local alignment search tool on the National Center for Biotechnology Information website), the trimmed sequences were screened for microsatellites using the SSR Hunter software (Li and Wan, 2005).

A total of 20 primer pairs were designed using the Premier 5.0 software (Clarke and Gorley, 2001) and tested using 90 individuals (30 individuals from each of 3 Huoyan goose populations). PCRs were performed in a final $25-\mu \mathrm{L}$ reaction volume containing $1 \mu \mathrm{L}$ genomic DNA ( $\sim 50 \mathrm{ng}), 1 \mu \mathrm{L}$ of each primer, $12.5 \mu \mathrm{L} 2 \mathrm{X}$ Taq PCR Master-Mix (Tiangen Biotech, Beijing, China), and 9.5 $\mu \mathrm{L} \mathrm{H}_{2} \mathrm{O}$. Microsatellite loci were amplified under the following conditions: 3 min denaturation at $94^{\circ} \mathrm{C} ; 30$ cycles of $1 \mathrm{~min}$ at $94^{\circ} \mathrm{C}, 1 \mathrm{~min}$ at optimized annealing temperature (each primer pair was tested separately, Table 1), 1 min at $72^{\circ} \mathrm{C}$; and a final extension at $72^{\circ} \mathrm{C}$ for $5 \mathrm{~min}$. PCR products were subjected to electrophoresis on $8 \%$ polyacrylamide gels for allele scoring. Gels were fixed in solution containing 10\% ethanol and 5\% acetic acid for $10 \mathrm{~min}$; stained with $0.1 \%$ silver nitrate for $10 \mathrm{~min}$; and visualized with $4 \%$ formaldehyde, $2 \%$ sodium hydroxide, and $0.4 \%$ sodium carbonate for $10 \mathrm{~min}$. Gels were analyzed using the Gel-Pro Analyzer software (version 4.5). Sizes of amplified microsatellite DNAs were determined by reference to a standard base pair ladder, DL 2000 (TaKaRa).

GenePop on the Web version 4.0.10 (Rousset, 2008) was used to calculate the allele number per locus $(A)$, observed heterozygosity $\left(H_{\mathrm{O}}\right)$, expected heterozygosity $\left(H_{\mathrm{E}}\right)$, and Hardy-Weinberg equilibrium expectations. The polymorphism information content (PIC) was calculated by the Botstein method (Botstein et al., 1980).

Table 1. Characterization of 8 microsatellite loci of Huoyan geese developed from an enriched genomic library.

\begin{tabular}{|c|c|c|c|c|c|c|c|c|c|c|}
\hline Locus & Primer sequences $\left(5^{\prime}-3^{\prime}\right)$ & Repeat motif & $\begin{array}{l}\text { Size } \\
\text { (bp) }\end{array}$ & Type & $\begin{array}{l}\mathrm{Tm} \\
\left({ }^{\circ} \mathrm{C}\right)\end{array}$ & $N_{\mathrm{A}}$ & $H_{\mathrm{O}}$ & $H_{\mathrm{E}}$ & PIC & $\begin{array}{c}\text { GenBank } \\
\text { accession No. }\end{array}$ \\
\hline HY20 & $\begin{array}{l}\text { F:ACCCGCATTCACCAT } \\
\text { R:TCAGCCAGGGAAAGTAG }\end{array}$ & $(\mathrm{TG})_{22}$ & 263 & $P$ & 60 & 3 & 1.0000 & 0.5923 & 0.5092 & KF171886 \\
\hline HY30 & $\begin{array}{l}\text { F:ATCAGTCTGCGTGGAG } \\
\text { R:CGGAATTACGTCGTTT }\end{array}$ & $(\mathrm{AC})_{10}(\mathrm{CA})_{5}$ & 239 & $\mathrm{C}$ & 60 & 4 & 1.0000 & 0.6327 & 0.5671 & KF207903 \\
\hline HY33 & $\begin{array}{l}\text { F:AGCGATGTTACTGTAGTGTT } \\
\text { R:GTGGCAGTGAGAATGAAA }\end{array}$ & $(\mathrm{TG})_{12} \mathrm{CG}(\mathrm{TG})_{5}$ & 179 & I & 60.7 & 3 & 1.0000 & 0.6372 & 0.5661 & KF207901 \\
\hline HY43 & $\begin{array}{l}\text { F:TCTCACTGTCTCATGCAC } \\
\text { R:TATCTAATGGAGCCGTAT }\end{array}$ & $(\mathrm{CA})_{45}$ & 260 & $\mathrm{P}$ & 53 & 4 & 0.6854 & 0.6462 & 0.5695 & KF207904 \\
\hline HY52 & $\begin{array}{l}\text { F:AGTAACTTGGACTGAGATG } \\
\text { R:GACTCAGCACTGGATATT }\end{array}$ & $(\mathrm{TG})_{16}$ & 139 & $\mathrm{P}$ & 50 & 2 & 0.7528 & 0.5000 & 0.3750 & KF207905 \\
\hline HY94 & $\begin{array}{l}\text { F:CAGGGTGACAGACAGAGG } \\
\text { R:ACGATCAGCCTGCTTCTA }\end{array}$ & $(\mathrm{GT})_{27}$ & 286 & $\mathrm{P}$ & 55 & 2 & 0.3556 & 0.2923 & 0.2496 & KF207907 \\
\hline HY110 & $\begin{array}{l}\text { F:TCTGTGGTCTGACCTTAT } \\
\text { R:GAGATGGTCTTCTTTTCA }\end{array}$ & $(\mathrm{AC})_{33}$ & 196 & $\mathrm{P}$ & 53 & 2 & 1.0000 & 0.5000 & 0.3750 & KF207908 \\
\hline HY58 & $\begin{array}{l}\text { F:ACTTCCCTTCTCCCACAG } \\
\text { R:TAATGGGTTACAGCTTGG }\end{array}$ & $(\mathrm{CA})_{20}$ & 232 & $\mathrm{P}$ & 61 & 4 & 1.0000 & 0.6868 & 0.6257 & KF207906 \\
\hline
\end{tabular}

$\mathrm{P}, \mathrm{I}$, and $\mathrm{C}=$ perfect, imperfect, and compound, respectively; $\mathrm{Tm}=$ annealing temperature; $N_{\mathrm{A}}=$ number of alleles; $H_{\mathrm{E}}=$ expected heterozygosity; $H_{\mathrm{O}}=$ observed heterozygosity; $\mathrm{PIC}=$ polymorphism information content.

\section{RESULTS AND DISCUSSION}

A total of 148 sequences were found to contain microsatellite repeats. Among the 148 microsatellites, $69.6 \%$ were perfect, $17.6 \%$ were imperfect, and the rest were compound type 
(12.8\%). Among 20 primer pairs, 8 primer pairs were amplified successfully with clear and single-locus bands. Details of the newly developed microsatellite loci are listed in Table 1. All the 8 loci showed polymorphism. The number of alleles per locus varied from 2 to $4 . H_{\mathrm{O}}$ and $H_{\mathrm{E}}$ ranged from 0.3556 to 1 and from 0.2923 to 0.6868 , respectively. The PIC per locus ranged from 0.2496 to 0.6257 . Hardy-Weinberg equilibrium tests demonstrated that all 8 of the polymorphic loci deviated from equilibrium.

The new 8 microsatellite loci presented here provide a tool to study genetic variation and population structure in Huoyan geese, and they will help in the design of conservation strategies.

\section{ACKNOWLEDGMENTS} \#31172286).

Research supported by the National Natural Science Foundation of China (Grant

\section{REFERENCES}

Botstein D, White RL, Skolnick M and Davis RW (1980). Construction of a genetic linkage map in man using restriction fragment length polymorphisms. Am. J. Hum. Genet. 32: 314-331.

Brown J, Hardwick LJ and Wright AF (1995). A simple method for rapid isolation of microsatellites from yeast artificial chromosomes. Mol. Cell. Probes 9: 53-57.

Cheng HH and Crittenden LB (1994). Microsatellite markers for genetic mapping in the chicken. Poult. Sci. 73: 539-546. Clarke KR and Gorley RN (2001). PRIMER v5: user manual/tutorial: PRIMER-E Limited, Plymouth.

Kamara D, Gyenai KB, Geng T, Hammade H, et al. (2007). Microsatellite marker-based genetic analysis of relatedness between commercial and heritage turkeys (Meleagris gallopavo). Poult. Sci. 86: 46-49.

Li Q and Wan JM (2005). SSRHunter: development of a local searching software for SSR sites. Yi Chuan 27: 808-810.

Li YC, Korol AB, Fahima T, Beiles A, et al. (2002). Microsatellites: genomic distribution, putative functions and mutational mechanisms: a review. Mol. Ecol. 11: 2453-2465.

Rousset F (2008). genepop'007: a complete re-implementation of the genepop software for Windows and Linux. Mol. Ecol. Resour. 8: 103-106. 